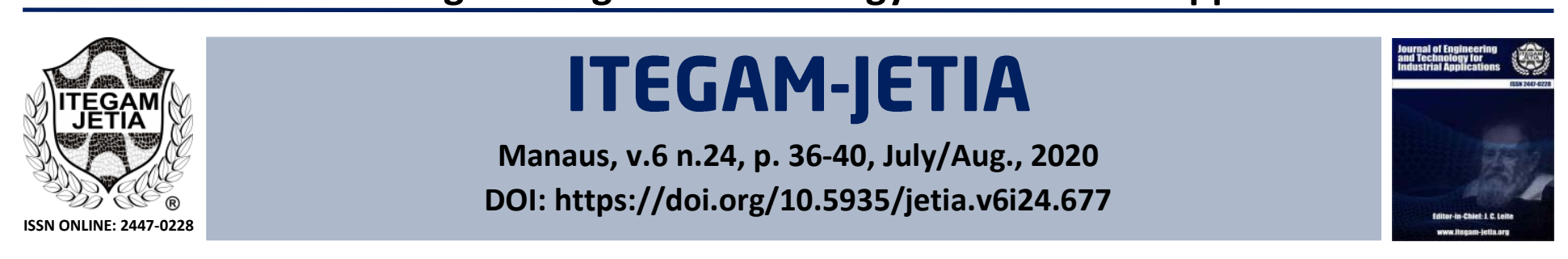

\title{
APPLICATION OF OPERATIONAL RESEARCH IN PROCESS OPTIMIZATION IN THE CEMENT INDUSTRY
}

\author{
Marcelo Carneiro Gonçalves ${ }^{1}$, Arthur Beltrame Canciglieri², Karolina Miranda Strobel ${ }^{3}$, Matheus \\ Felipe Antunes ${ }^{4}$ and Rafaela Richa Zanellato ${ }^{5}$ \\ 1, 2, 3, 4, 5 Pontifical Catholic University of Paraná - PUCPR. Curitiba-Paraná, Brazil.
}

Email: carneiro.marcelo@pucpr.br, artcanci_98@hotmail.com, karolstrobel@gmail.com, matheusantunesfelipe@gmail.com, rafazanellato@hotmail.com

\section{ARTICLE INFO}

\section{Article History}

Received: July $19^{\text {th }}, 2020$

Accepted: August $12^{\text {th }}, 2020$

Published: August $31^{\text {th }}, 2020$

\section{Keywords:}

Operations Research,

Linear Programming,

Construction Industry.

\begin{abstract}
One of the largest economic sectors in Brazil is the construction industry, being an important segment for investments in the country. As a result, it is a firmly established sector which has attained a high level of competitiveness. However, given the dynamic approach necessary in a world of accelerated change, the construction industry faces a wide range of challenges which must be addressed so to maintain, and if possible, improve its competitiveness. This study aims to determine how to maximize the profit of a construction company located in Curitiba, Paraná state, applying techniques of Operations Research, an analytical method of problem-solving and decision-making. The tool used to perform the optimization was Linear Programming, a mathematical modeling technique in which a linear function is maximized or minimized when subjected to various constraints. The results show a strong possibility of increasing the company's profit by production leveling.
\end{abstract}

\section{INTRODUCTION}

One of the largest economic sectors in Brazil and in the world is that of civil construction, being one of the most important spheres of investment in a country resulting in infrastructure, both at home and for companies and industries. The country's economic result is highly linked to construction indicators, since when a country has a favorable economic scenario, it tends to build and warm up the real estate market. However, in recent years, the Brazilian construction market has fallen due to political and economic instability, resulting in the entire construction materials logistics chain having low sales volume and having to rethink their strategies and costs.

In this context, the largest cement factory in Latin America has three industrial complexes to produce its entire product portfolio, and until 2012 and mid-2013 it was used to its maximum production potential, however from 2013 with crises in the constructions only 1 complex is in operation not reaching maximum production capacity.

In order to reduce the consequences of falling volumes, the company saw the need to reinvent itself and apply new methods of controlling costs and profits, in line with current market scenarios.
For this, the product portfolio and how they were offered to the end customer were totally redesigned, in order to facilitate their purchase and use. In addition, the company began to apply simple linear programming methodologies to understand how its production leveling and portfolio could reduce costs and maximize profits.

This work, therefore, aims to apply Linear Programming techniques to maximize the company's profit on top of the main products, that is, only the cement and not the complementary products, considering variables of cost and profit of the sectors of production, commercial and shipping. For that, the 4 main products will be used. In addition, to create a fast and simple linear programming tool, so that managers can make decision-making instantly if the market scenario changes, thus minimizing the impact of future crises and maximizing profit in positive scenarios.

\section{THEORETICAL REFERENCE \\ II.1 OPERATIONAL RESEARCH}

According to [1], Operational Research originated during World War II, where the Allied support teams had to solve various 
logistical and tactical problems involved in the highly complex military strategy, which would result in saving the lives of their soldiers. Multidisciplinary groups of engineers, physical mathematicians and others were created to solve these problems, in order to preserve resources, whether human or material, since this control would win the war.

Since the end of the war, several companies saw the opportunity to invest in operational research tools and thus maximize their profits and minimize their costs, so that it became popular as a tool already in the reconstruction of post-war destroyed Europe. Currently in Brazil, Operational Research (PO) is an area of Production Engineering that provides professionals with tools for managing an organization's human, material and financial resources. According to [2], applications of PO and its tools are common in different sectors of daily life, such as in industries, in the transport of material and people, in the area of health, education, agribusiness, in the area of finance, in economy and public sectors.

In fact, Operational Research covers a range of areas, models and algorithms that allow managers to make decisions on complex problems. It is possible, in a simplified way, to subdivide the resolution of a problem by the PO in five stages: Problem Formulation (System Identification); Construction of the Mathematical Model; Obtaining the Solution; Testing the Model and the Solution Obtained and its Implementation [3].

\section{II.2 MATHEMATICAL PROGRAMMING}

According to [4], programming and mathematical optimization models have two general forms of use. The first type is when the mathematical model is used at the strategic level of the organization, being long-term resolutions and more important decisions, having to evaluate a greater number of variables and their real impact on the organization. The second type of mathematical modeling is used at the tactical-operational level, where the scenario can change daily and the model must be simple and quick to be implemented, without losing its accuracy of reality, serving as a tool for managers to take minor actions.

In the conceptualization of a mathematical model, three main elements are inserted: the first being the decision variables that are the unknowns to be determined by the solution of the model, often being interpreted as the portfolio of products to be produced. The second element being the restrictions: in order to consider, the physical limitations of the system, the restrictions of production and material, of the market, of storage, among others. And thirdly, the objective function: it is a mathematical function that defines the solution based on the decision variables and their restrictions, so that the best answer to the proposed problem is evaluated [5].

\section{II.3 LINEAR PROGRAMMING}

According to [6] Linear Programming is a robust planning technique to solve numerous problems. Its results are mainly separated into two elements: the increase in profits and the decrease in costs, being a tool implemented daily in most companies in the world, given its efficiency and speed of modeling. The Linear Programming model is applied to situations of scarce resources, with the intention of reaching a certain objective, usually to maximize or minimize its variables, to choose the best possible scenario within the countless options that can be taken.
[5] conceptualizes linear programming as a tool used to analyze models where the constraints and the objective function are linear - straight. Linear models are versatile tools, of medium mathematical complexity and that require almost no computational effort to find the optimal solution in most of the problems presented. In addition, linear problems and linear programming can be easily contextualized and are easy to understand by the entire body of developers, thus facilitating their understanding and use.

The first great effective model to solve a Linear Programming Problem was the Simplex algorithm, developed in 1947 by Dantzig, which will be addressed in this work. Despite having exponential complexity, which means that when adding variables, the problem grows in complexity of resolution exponentially. Although Simplex is an old method and has several limitations in the representation of more complex problems, it is a model still widely used today, due to its ease of operation and understanding [7].

\section{II.4 SOFTWARE}

According to [8] the application of operational research tools has always created a feeling of frustration because they are complex mathematical models and difficult to understand on the factory floor. However, at present several advances have been made to reduce this pain, creating software that simplified its application and thus disseminating the knowledge of operational research. In this context, the Microsoft Excel program created and adapted optimization models through data analysis modules, thus facilitating the use of operational research models with its data tabulation. These tools are now found in the Solver Module, which allows solving optimization problems described through equations written in the spreadsheet cells.

According to [9] with the use of the solver, it is possible to obtain an ideal value (maximum or minimum) for a cell, called an objective cell, obeying the restrictions, or limits, on the values of other cells in a spreadsheet. This creates a very powerful tool for managers, since most of them are already familiar with Excel software and thus can use operational research models to solve problems in a way never seen before.

In addition, the Excel and its complement solver allows the rapid change of scenario and variables within their banknotes, thus making the calculation of an optimal scenario, almost easy for everyone, to make decision making more reliable almost instantly. and ensured in mathematical-scientific methods.

\section{II.5 MODELING}

According to [10], modeling is used in several situations that require a solution or decision making. The situation is modeled to simulate possible scenarios that configured alternatives for decision making related to a solution. In other words, modeling offers information to verify the best solutions to a problem and thus find an optimal solution. When it comes to optimization problems, it means that we want to maximize (increase) or minimize (decrease) a function, related to finance, production, among other areas. In such cases, it is necessary to check the objective function and the restrictions presented by the analyzed system.

The first step in modeling is the choice of decision variables. As in most PL problems, the decision variables represent the quantities of products sold, which must be positive values, that is, greater than zero. The second step is to create the 
constraints and define the objective function of the problem. In the objective function, it must represent the main objective of the problem, which can be to maximize profit or minimize costs, for example, while the restrictions can be capital, quantity and/or space, they are usually variables such as availability of raw material, capacity production, labor and price limitations [11].

According to [12], when defining the problem restrictions, you must first check the factors that may limit production, so that it is then possible to obtain the optimal solution considering the most important factors of the company. The simplex method seeks, if any, one or more solutions from a basic feasible solution, generating a sequence of feasible solutions. When this sequence is completed, the optimal solution is obtained.

\section{DEVELOPMENT}

As already mentioned, the company under study operates in the civil construction area, producing cements, mortars, concrete and aggregates. This work focused only on the production of cement, which is divided into 4 types. They differ in the area of construction that are applicable and for that use different amounts of some raw materials such as plaster, slag and and pozzolana.

The company uses four major pillars as the north, they are: Focus on the customer, always aiming at the customer's need, having specific business models to serve the customers. The second pillar is People with Autonomy, which seeks to value leaders by creating strong, diverse and engaged teams, always working together creating solutions, seeking smart synergies aiming at gains for all. The third pillar is Operational Excellence using performance monitoring and always seeking continuous improvement by making decisions with speed, discipline and consistency, maximizing productivity in all areas. And the last pillar of Sustainable Practices, always placing safety in first place, acting ethically and always in accordance with the laws, also promoting eco-efficiency.

Always seeking to meet the four pillars mentioned above, products can be found from different brands according to the region, that is, after a study of the needs of each region of the country, this division was made into four brands that serve the South region, Southeast, Center-North and Northeast.

The products are then differentiated from the needs of the regions as shown above and within each region it is divided into the types that are studied in this report, Type I, Type II, Type III and Type IV. What differs from them is where they will be applied and the raw materials.

The company's production line has its own limestone extraction mine, which is transported by cable car to the factory, after crushing to result in smaller stones, the limestone is mixed with clay and iron ore in mills until form a kind of flour, which is called Raw Flour, as soon as the flour is mixed, it is stored in silos, after the flour is taken mechanically to the oven, in the oven it will turn into Clinker, which is the cement base, called of "pure cement", (the kiln uses petroleum coke), after leaving the kiln the clinker is cooled and stored in silos until it is milled to be mixed with plaster, slag and pozzolan depending on what type of cement will be produced. So, you have the final product, which is stored and either goes to bagging or silos (in bulk sale) until it is transported to customers.

This project seeks to maximize profit from the production of 4 different cement models. For that, the following data were collected for the construction of the mathematical model:
- Sales: The expected market demand is 2200 tons with a $10 \%$ margin of error. In addition, there is a minimum demand of 200 tons for each product.

- Purchasing: Each type of cement consumes different amounts of limestone, iron ore, clay and plaster. Fixed quantities of raw material are purchased on a contractual basis.

- HR: How many people are used to produce per ton of each product/month, since some products go through different processes for their specific characterization. The production line has about 50 operators who can manufacture any of the four products.

- Production: What is the production time (bottleneck machine) to produce the ton of each type of product. They are produced in 2 shifts of $8 \mathrm{~h}$ each considering 20 consecutive days in the month (totaling $320 \mathrm{~h} /$ month of production).

- Logistics: How much does all internal logistics and packaging cost to produce each type of cement/ton. The company's goal is to spend less than $\mathrm{R} \$ 250,000.00$.

Table 1 below represents the demand forecast with an error of $10 \%$ (in tons), the quantity used of each raw material (in tons), the consumption of labor (workers) per product, the time required for production (in hours), the logistical cost of each cement (in reais), as well as the unit profit obtained from the production of each model.

Table 1: Data Collection.

\begin{tabular}{|r|c|c|c|c|c|}
\hline & $\begin{array}{c}\text { Ciment } \\
1\end{array}$ & $\begin{array}{c}\text { Ciment } \\
2\end{array}$ & $\begin{array}{c}\text { Ciment } \\
3\end{array}$ & $\begin{array}{c}\text { Ciment } \\
4\end{array}$ & Limits \\
\hline Total demand & 1 & 1 & 1 & 1 & $1980<\mathrm{x}<2420$ \\
\hline $\begin{array}{r}\text { Amount of } \\
\text { Limestone }\end{array}$ & 1,8 & 2,3 & 2,7 & 4 & 5250 \\
\hline Amount of Iron & 1 & 2 & 2,5 & 3 & 4080 \\
\hline Amount of Clay & 0,9 & 0,3 & 0,1 & 0,5 & 1150 \\
\hline $\begin{array}{r}\text { Amount of } \\
\text { Plaster }\end{array}$ & 1 & 0,8 & 5 & 0,5 & 1652 \\
\hline Workforce & 0,018 & 0,023 & 0,027 & 0,03 & 50 \\
\hline $\begin{array}{r}\text { Production } \\
\text { Time }\end{array}$ & 0,1 & 0,2 & 0,16 & 0,14 & 320 \\
\hline Logistic Coast & 100 & 115 & 140 & 130 & 250000 \\
\hline Profit & 1400 & 2300 & 3000 & 4000 & Max \\
\hline
\end{tabular}

Source: Authors, (2020).

\section{III.1 MATHEMATICAL MODEL}

Next, the declarations of the decision variables were made to then enter the model, below the variables, restrictions and mathematical model of the problem are presented.

\section{Variables:}

- X1: Type I cement;

- X2: Type II cement;

- X3: Type III cement;

- X4: Type IV cement

\section{Restrictions:}

- RV1: Sales restriction 1, minimum expected total demand;

- RV2: Sales restriction 2, maximum expected total demand;

- RV3: Sales restriction 3, minimum cement demand for all works;

- RV4: Sales restriction 4, minimum demand for cement structural works;

- RV5: Sales restriction 5, minimum demand for cement special works - industrial; 
- RV6: Sales restriction 6, minimum demand for cement special works - aggressive means;

- RC1: Restriction of purchases 1, quantity of limestone;

- RC2: Restriction of purchases 2, quantity of iron;

- RC3: Restriction of purchases 3, quantity of clay;

- RC4: Restriction of purchases 4, quantity of plaster;

- RRH1: Restriction of human resources, number of operators;

- RP1: Production restriction, production time;

- RL1: Logistics restriction, internal logistics cost.

\section{Linear Programming Model:}

The mathematical model is presented below.

Objetive Function:

Maximum $\mathrm{f}(\mathrm{x})=1400 * \mathrm{x} 1+2300 * \mathrm{x} 2+3000 * \mathrm{x} 3+4000 * \mathrm{x} 4(1)$

RV1:

$$
x 1+x 2+x 3+x 4>1980
$$

RV2:

$$
x 1+x 2+x 3+x 4<2420
$$

RV3:

$$
x 1>200
$$

RV4:

$$
x 2>200
$$

RV5:

$$
x 3>200
$$

RV6:

$$
x 4>200
$$

$\mathrm{RC} 1$ :

$$
1.8 * \mathrm{x} 1+2.3 * \mathrm{x} 2+2.7 * \mathrm{x} 3+4 * \mathrm{x} 4<5250
$$

RC2:

$$
1 * \mathrm{x} 1+2 * \mathrm{x} 2+2.5 * \mathrm{x} 3+3 * \mathrm{x} 4<4080
$$

RC3:

$$
0.9 * \mathrm{x} 1+0.3 * \mathrm{x} 2+0.1 * \mathrm{x} 3+0.5 * \mathrm{x} 4<1150
$$

RC4:

$$
1 * \mathrm{x} 1+0.8 * \mathrm{x} 2+5 * \mathrm{x} 3+0.5 * \mathrm{x} 4<1652
$$

RRH1:

$$
0.018 * \mathrm{x} 1+0.023 * \mathrm{x} 2+0.027 * \mathrm{x} 3+0.03 * \mathrm{x} 4<50
$$

RP1:

$$
0.1 * \mathrm{x} 1+0.2 * \mathrm{x} 2+0.16 * \mathrm{x} 3+0.14 * \mathrm{x} 4<320
$$

RL1:

$$
100 * \mathrm{x} 1+115 * \mathrm{x} 2+140 * \mathrm{x} 3+130 * \mathrm{x} 4<250,000
$$

Non-negative:

$$
\mathrm{x} 1, \mathrm{x} 2, \mathrm{x} 3, \mathrm{x} 4>0
$$

\section{RESULTS}

In order to achieve the result of the model above, restrictions were inserted in Excel, so that with the help of the Solver supplement, it was possible to find the optimal solution, in order to maximize the company's profit. Table 2 below shows the output results of the decision variables and the maximum profit obtained:

Table 2: Optimized production result.

\begin{tabular}{|c|c|}
\hline Product & Tons \\
\hline Ciment I & 584 \\
\hline Ciment II & 460 \\
\hline Ciment III & 464 \\
\hline Ciment IV & 472 \\
\hline Max Profit/Month & R\$ 5.155.600,00 \\
\hline
\end{tabular}

Source: Authors, (2020).

Therefore, the best solution found for the company's production mix is to produce 584 tons of Type I cement, 460 tons of Type II cement, 464 tons of Type III cement and finally 472 tons of Type IV cement - aggressive media. Despite a certain variance, it is possible to see that this optimized solution also resulted in a level production between the 4 products, which distributes resources efforts more evenly and makes it possible to satisfy a larger portfolio of customers, helping the company in general.

In addition, it was possible to carry out an analysis of the restrictions to understand which ones would be used to their limits and which ones would have clearances. This is shown below in Table 3.

Table 3: Analysis of excess resources.

\begin{tabular}{|c|c|c|c|c|}
\hline Restriction & Limits & $\begin{array}{c}\text { Quantity } \\
\text { Used }\end{array}$ & $\begin{array}{c}\text { Leftover } \\
\text { resources }\end{array}$ & \% Leftover \\
\hline RV1 and RV2 & $1980<\mathrm{x}<2420$ & 1980 & - & - \\
\hline RC1 & 5250 & 5250 & 0 & $0 \%$ \\
\hline RC2 & 4080 & 4080 & 0 & $0 \%$ \\
\hline RC3 & 1150 & 946 & 204 & $18 \%$ \\
\hline RC4 & 1652 & 1652 & 0 & $0 \%$ \\
\hline RRH1 & 50 & 43 & 7 & $14 \%$ \\
\hline RP1 & 320 & 290.72 & 29.28 & $9 \%$ \\
\hline RL1 & 250 & 237.62 & 12.38 & $5 \%$ \\
\hline
\end{tabular}

Source: Authors, (2020).

It is possible to observe with the figure above that the restrictions that are not being fully used to maximize the company's profit are those of purchases in the amount of clay $(18 \%)$, human resources in the number of operators required in the production line $(14 \%)$, the time required for production $(9 \%)$ and the costs of internal logistics and packaging for the production of each type of cement $(5 \%)$. With this it is possible to take actions to reallocate these resources to other areas (such as operators) or to cut inventory expenses, as in the case of clay, which is provided for in the optimized system, which accounts for over $18 \%$ of the total purchased, and thus obtain the same revenue with less resources and even cut expenses that can decrease the expenses of the production line.

On the other hand, it is also possible to increase the resources that are being used in their entirety, since there is expected demand for more products and the bottleneck is the internal resources fully used. For this, the quantities purchased of limestone, iron ore and plaster would have to be increased in order to increase production and, consequently, turnover in 
search of a greater profit. In this context, a sensitivity analysis was carried out to understand the change in total profit by increasing these resource bottlenecks to enable increased production in an optimized system.

\section{IV.1 SENSITIVITY ANALYSIS}

The sensitivity analysis seeks to determine the effect of the variation of a given resource on the total objective value, which in this study is the company's profit. It is a very useful tool in different areas to determine the importance of increasing or decreasing resources and obtaining results even better than the current state. Therefore, a Dual sensitivity analysis was performed so that it was possible to perceive the variation that the objective function would undergo in the variation of the limits of the restrictions. The result of the sensitivity analysis is shown below in Table 4.

Table 4: Sensitivity analysis.

\begin{tabular}{|c|c|c|c|}
\hline $\begin{array}{c}\text { Resource } \\
\text { Restriction }\end{array}$ & $\begin{array}{c}\text { Value of } \\
\text { restricti } \\
\text { on }\end{array}$ & $\begin{array}{c}\text { Maximum amount of } \\
\text { increment for } \\
\text { changing the } \\
\text { bottleneck resource }\end{array}$ & $\begin{array}{c}\text { Profit variation } \\
\text { with unit } \\
\text { increment of } \\
\text { resource }\end{array}$ \\
\hline $\mathrm{RC} 1$ (Limestone) & 5250 & 130 & $\mathrm{R} \$ 706,67$ \\
\hline $\mathrm{RC} 2$ (Iron) & 4080 & 223.1707 & $\mathrm{R} \$ 642,67$ \\
\hline $\mathrm{RC} 4$ (Plaster) & 1652 & 65 & $\mathrm{R} \$ 480,00$ \\
\hline
\end{tabular}

Source: Authors, (2020).

Table 4 indicates that by increasing 1 ton (unit increment) the quantities of either limestone, or iron ore or plaster, would have an increase in profit of $\mathrm{R} \$ 706.67, \mathrm{R} \$ 642.67$ and $\mathrm{R} \$ 480$ respectively. This analysis becomes an important tool for the purchasing manager to see if it is feasible and desirable to increase these resources to increase cement production, since if the cost of a ton of these resources is less than the profit obtained, it would be interesting to implementation of larger purchases. In addition, the increase can be made up to the maximum number of increments indicated in Table 4 before there is a change in the bottleneck resource scenario, where a new sensitivity analysis must be made to understand what the current bottleneck resources are and thus make continuous improvements.

\section{CONCLUSIONS}

In this work it was possible to present a real case of the application of operational research for decision making with the aid of linear programming, with the main objective of maximizing profits and showing a quantified direction to reduce waste and bottlenecks. Thus, making it possible to provide the company with a tool that enhances its contribution margin, optimizing its product mix.

In addition, with the sensitivity analysis, it was evident that the company has significant leftover raw materials, number of operators, production time and the cost of internal logistics. With this type of leveling proposed, the company will be able to eliminate excessive variability in production, making it more repetitive and predictable. With this, it will make it possible to identify the quantities of raw materials and finished products that are really necessary to keep in stock, which makes it possible to reduce the number of items stocked, increasing the flexibility of response to the customer and making production closer to real demand, with a constant pace and following quality standards. In this way, the company will be able to dimension its resources better, becoming more competitive.

\section{ACKNOWLEDGMENTS}

The authors would like to thank Pontifical Catholic University of Parana (PUCPR) for the support to the development of this research.

\section{REFERENCES}

[1] Mello, J. C. C. B.; Mello, M. H. C. S. Integração entre o ensino de cálculo e o de pesquisa operacional. Revista Produção, v. 13, n. 2, p. 123, 2003.

[2] Maculan, N. E Fampa M.H.C., Otimização Linear, Editora UnB, Brasília, 2006.

[3] Marins, Fernando Augusto Silva. "Introdução à pesquisa operacional." São Paulo: Cultura Acadêmica: Universidade Estadual Paulista (2011).

[4] Ignácio, A.A.V. and Ferreira Filho, V.J.M., 2004. Seção de Software: o uso de software de modelagem AIMMS na solução de problemas de programação matemática. Pesquisa Operacional, 24(1), pp.197-210.

[5] Lisboa, Erico Fagundes Anicet. "Pesquisa operacional." Apostila da disciplina. Rio de Janeiro-RJ (2002).

[6] De Moraes, D.G., Ferreira, C.V. and DA Silva, A.M., 2019. Otimização da produção utilizando Programação Linear: estudo de caso em uma indústria de esquadrias de alumínio. Refas-Revista Fatec Zona Sul, 5(4), pp.26-37.

[7] Fonseca, F.F. and Pinto, L.L., 2013. Uma ferramenta de apoio para professores e estudantes em cursos de Pesquisa Operacional. Anais do XLV Simpósio Brasileiro de Pesquisa Operacional, Natal/RN, pp.824-831.

[8] Casnav, M.D.S., UFF, A.C.P. and CETIQT, M.F.D.R.S., 2016. Proposta de otimização do mix de produção utilizando o Método Simplex: um estudo de caso de uma confecção de moda íntima do município de Cordeiro-RJ.

[9] Stacanelli, T. M. et al. Aplicação da Programação Linear para a otimização da produção em um laticínio localizado na região centro-oeste de Minas Gerais In: Encontro Nacional de Engenharia de Produçâo, 35, Fortaleza. Anais do Encontro Nacional de Engenharia de Produção, Rio de Janeiro: ABEPRO, 2015.

[10] Rodrigues, Rodrigo. Pesquisa Operacional. Associação Brasileira de Direitos Reprográficos Porto Alegre, 2017

[11] Colin, C., E. Pesquisa Operacional - 170 Aplicações em Estratégia, Finanças, Logística, Produção, Marketing e Vendas, $2^{\text {a }}$ edição. 2018.

[12] Pezzi Godinho Ilza e Corso Leandro Luís. 2019. Aplicação da Programação Linear para otimizar o mix de produtos em uma empresa de confecção feminina e masculina situada na Serra Gaúcha. 